\title{
THE INTERFACE BETWEEN PERCEPTION, EVIDENTIALITY AND DISCOURSE PARTICLE USE - USING A TRANSLATION CORPUS TO STUDY THE POLYSEMY OF SEE ${ }^{1}$
}

Karin Aijmer*

\begin{abstract}
One of the most striking characteristics of the lexicalisation patterns of the verbs of perception is the large amount of polysemy.
\end{abstract}

(Viberg, 1984:136)

\begin{abstract}
The general aim of the article is to show how translations can be used to study polysemy. The particular research problem is to investigate the extent to which see has extended its meaning into new semantic domains on the basis of its translations into other languages. The data are taken from the English-Swedish Parallel Corpus. At a general level, the English verb see and the Swedish verb se are similar to each other as might be expected from the fact that they are etymological and semantic cognates. Both refer to the situation of perceiving with one's eyes but the verbs diverge in their further developments. It is shown that see extends its meaning into semantic domains such as evidentiality, aspect, causation and discourse, and that the development depends to a large extent on the context, in particular complementation.
\end{abstract}

KEYWORDS: perception, evidentiality, 'see', polysemy, translation corpora, translation evaluation.

RESUMO: O objetivo geral deste artigo é demonstrar como traduções podem ser usadas para estudar a polissemia. $O$

* English Department, Göteborg University, Sweden.

1 I am grateful to Göran Kjellmer for reading an earlier version of the article.

TradTerm, 10, 2004, p. 249-277 
problema de pesquisa especifico é investigar, com base nas suas traduções para outras línguas, o quanto o verbo see estendeu seus significados avançando para novos campos semânticos. Os dados são extraidos do Corpus Paralelo Inglês-Sueco. No plano geral, o verbo inglês see e o verbo sueco se são semelhantes, como era de se esperar por serem cognatos etimológicos e semânticos. Ambos referem-se à percepção com os olhos, mas divergem em outras esferas. Demonstra-se que see estende seus sentidos para campos como evidência, aspecto, ação causativa e discurso, e que o desenvolvimento depende, em grande parte do contexto, em especial de estruturas de complementação.

UNITERMOS: percepção; evidência; verbo see; polissemia; corpora de tradução; avaliação de tradução.

\section{Introduction}

In all languages there are words referring to basic human experiences or phenomena such as seeing, hearing, tasting, smelling. It could be expected that such words in one language would have direct correspondences in other languages. When we look more closely at translation equivalents of perception verbs in two or more languages, the picture is more complex. The situation is characterised by a kind of linguistic relativity: languages have similar words but use them differently.

Altenberg \& Granger (2002:22) use the term 'diverging polysemy' to refer to the fact that items in two languages may have different meaning extensions. Even cognates with the same basic meaning may diverge in their further developments. For example, in English and Swedish we find pairs of verbs such as go/gå and see/se which have the same basic meaning. Bilingual or multilingual corpora make it possible to explore both similarities and differences between languages on the basis of empirical data. In a study based on translations from English into Swedish and Swedish into English taken from the EnglishSwedish Parallel Corpus, Viberg (1996) found that go and its

TradTerm, 10, 2004, p. 249-277 
Swedish cognate $g a ̊$ were correspondences in only one third of the examples. The present paper will discuss see and its different meanings on the basis of data from the English-Swedish Parallel Corpus. Like go, the verb see is highly polysemous and therefore a fruitful topic for cross-linguistic study. An interesting question that can be illustrated by means of corpora is the extent to which this verb has extended its meanings into the cognitive and evaluative semantic domain.

When a word is polysemous, its different meanings may be reflected in its translations to another language. Paradigms of translation correspondence can therefore provide the data for studying the different meanings and functions of a lexical item. In order to analyse the polysemy of see I have assumed that see has a basic meaning functioning as a prototype from which new meanings can be created by extension. The notion of prototype explains that see intuitively means 'perceiving with one's eyes', while the regularity of the developments from this core, both synchronic and diachronic, is the result of grammaticalisation.

The processes involved in the semantic extension of see are for instance implication, amalgamation and metonymy (standing for something else). Extensions can also be discussed in terms of grammaticalisation (semantic bleaching and the development of grammatical functions) and pragmaticalisation (the development of discourse functions by pragmatic strengthening). Also the wider context, including speakers' world knowledge, is important for the meaning extensions of see. The meaning of perception verbs also involves grammar, in particular complementation. The aktionsart of the verb may also be involved in the shifts in the interpretation of see.

The methods for studying polysemy in a contrastive perspective are discussed in Section 2. The complementation of see is the topic of Section 3. The translation paradigms resulting from comparing see and its correspondences in Swedish are dealt with in Section 4. Section 5 discusses see and evidentiality. In the main part of this paper a distinction is made between see as a perceptual verb (Section 6) and see as a cognitive verb (Section 7) on the basis of the translations in the English-Swedish Parallel Corpus. See as a perceptual verb includes the senses resulting

TradTerm, 10, 2004, p. 249-277 
252

from its extensions to new 'social' meanings, in which case the meaning 'perceiving with your eyes' is only implied among new grammatical meanings.

When see is not a perception verb it has conceptual, evidential or evaluative meanings, as shown in the translations. Translations where see is not translated also indicate that see is no longer a perceptual verb but has developed grammatical functions (Section 8).

\section{Methods and material}

The verbs of perception have been studied from a typological perspective on the basis of extensive samples of world languages (Viberg, 1984). The present study is based on a smaller material of only two languages (English and Swedish) and is restricted to the verb see rather than the whole semantic domain of perception. The methodology involves the use of translation corpora and has been described in recent articles and books (see e.g. Altenberg \& Aijmer, 2000; Johansson \& Oksefjell, 1998; Hasselgård \& Oksefjell, 1999).

Translation corpora can be used for several purposes. For example, translations can provide empirical data about meaning distinctions which may support data from a monolingual corpus (cf. Alm-Arvius, 1991 on the polysemy of see). In this study, the English-Swedish Parallel Corpus will be used to analyse the dimensions or semantic features which are needed to describe the meanings of the English verb see.

The English-Swedish Parallel Corpus (ESPC) consists of English texts translated into Swedish and Swedish texts translated into English (cf. Altenberg \& Aijmer, 2000). Its present size is 2.5 million words. Both fiction and non-fiction texts are represented in roughly equal proportions in the corpus. There is a balance between text types in the paired languages so that for instance children's books are represented in equal proportions in both languages. A translation corpus is aligned sentence-bysentence and incorporates software for searching the corpus. The design of the corpus makes it possible to search for words

TradTerm, 10, 2004, p. 249-277 
and constructions in either translation direction (English-Swedish or Swedish-English) or in both. It is also possible to compare English and Swedish original texts. For the present analysis I have mainly used translations from English into Swedish of the verb see. Only fiction texts have been included.

\section{See and complementation}

The most important factor explaining the meanings of see is complementation according to Usoniene (2001). The pattern of clausal complementation with see is extremely varied. The range of complementation is illustrated by the following sentences:

\section{Perceptual}

He saw the house.

He saw the cup shatter.

He saw them crossing the bridge.

Evidential

He saw that the bridge had been destroyed.

\section{Cognitive}

Do you see what I mean?

\section{Evaluative}

I see it as an advantage.

(Examples adapted from Miller \& Johnson-Laird, 1976: 598)

He saw the cup shatter (event proposition) and he saw them crossing the bridge (most often a process proposition) imply an immediate relation between what is perceived and the perception (purely sensory perception or direct perception; Usoniene, 2001:20). See refers to the truth of the proposition in a metalinguistic way when it is followed by a that-clause or by a wh-clause (cf Miller $\&$ Johnson-Laird, 1976: 598). In I see that your new book has just come out, I see is an evidential marker expressing a conclusion (compare I feel that [= I think that], I hear that [= it is reported that]). There is, however no consensus on whether a that-clause (or paraphrasability by a that-clause) is always indicative of the conceptual, rather than perceptual nature of the complement' (cf. Noël, 2002: 85). I will return to this problem in Section 5.

TRadTerm, 10, 2004, p. 249-277 


\section{Overall results of the investigation}

See is one of the most frequent verbs in English occupying rank 12 among the 50 most frequent verbs in English based on Francis and Kucera (1982) (Viberg, 1996:156). In the ESPC there were 772 tokens (in the fiction part)..$^{2}$ In $69.3 \%$ of the cases see was translated by a cognate form in Swedish suggesting that the corresponding verbs have developed differently in about one third of the cases. The fact that we do not find a hundred per cent correspondence between cognates is probably characteristic of nuclear verbs (e.g. go, come, make, take, give, say, see) and other highly exploited verbs (Viberg, 1996:161). In the opposite translation direction (Swedish $\rightarrow$ English) the percentage of corresponding cases was $73.1 \%$ (based on 930 examples excluding idioms with se), ${ }^{3}$ which indicates a fairly high correspondence between see and se.

The most frequent translation is se (Appendix 1: Table 1a $-1 \mathrm{~d})$. See in different tenses has been presented separately. The reason is that see was more frequent in the past tense with the translation förstå ('understand'). Table 1e organises the translations according to meaning. ${ }^{4}$ The translations of see indicate that the verb can have different aspectual meanings ( $f a$ se 'get to see', få syn på cf. 'catch sight of' besides kan se 'can see'). See also has meanings which have nothing to do with perception. One category of translations consists of examples where the meaning of see implies social contact (träffa, möta 'meet', prata med 'talk to'). See can also be used as a near-synonym of read (Swe. translation 'läsa'), which implies seeing: if you read something you must be able to see it. Seeing can be an activity with or without an intentional component (titta på 'look at', kontrollera

2 Some uses of see and their translations have been treated as idiomatic (see as a particle verb, discourse particle uses, fixed collocations between verb+noun, fixed complex verb phrases). They have not been counted but are given with translations in Appendix 2.

3 Some of the Swedish idioms are illustrated in Appendix 3.

4 The translations of the different forms of the lemma are presented in separate tables since the form of the verb also seems to affect the interpretation. However, this will not be further discussed here.

TradTerm, 10, 2004, p. 249-277 
'check to see', cf. Section 7). Many translations occurred only once (19 examples) indicating that a number of specific implications can be rendered in the translations.

When see belongs to the semantic field of cognition, this is signalled in translations such as förstå 'understand', begripa 'understand', fatta 'grasp', inse 'realise'. Other cognitive meanings include those where see is translated by finna 'find' or märka 'notice' rather than by se 'see'. Purely evaluative meanings of see have translations such as betrakta (som), se (som), uppfatta (som) ('see as', 'regard as'). In the main part of my paper I will look in more detail at the translations. In some cases see was for instance not translated at all. Such examples suggest that see has a weakened meaning and has developed grammatical meaning.

\section{See and evidential meaning}

Chafe \& Nichols's (1986) study of evidentiality shows that direct sensory data is considered to be the most certain type of knowledge. Chafe (1986) discusses examples such as I saw her coming down the street where see indicates that reliable evidence has been derived from sensory evidence. The knowledge based on seeing is high on reliability as demonstrated by the fact that the speaker could also have said She's coming down the street without any evidential specification. The mode of knowing expressed by see is induction based on seeing (Chafe, 1986: 263, 267).

The syntactic behaviour of the verb is important for its interpretation. For example, I saw that he crossed the street does not necessarily mean the same thing as I saw him cross the street. Another difference is between I saw him cross the street and I saw him crossing the street. In the first sentence the proposition refers to an event; in the second example, the proposition can also be a process. Some examples from the corpus and their translations are:

See+NP+Ving

(1) Andrew was surprised to see tears brimming in the burly Texan's eyes.

(AH1)

TRADTERM, 10, 2004, p. 249-277 
256

Andrew såg till sin förvåning tårar i den storväxte texasbons ögon.

(lit. 'Andrew saw to his surprise tears in the burly Texan's eyes')

See+NP+Vinf

(2) The horse had won handsomely and given him a taste for future ownership, though he seldom went to see his horses run, which wasn't particularly unusual in an owner but always to me mystifying.

(DF1)

Hästen sprang in mycket pengar och Greville fick smak på att äga hästar i fortsättningen, även om han aldrig såg dem löpa, vilket inte var särskilt ovanligt för en hästägare men alltid svårt för mig att förstå.

See +NP+ Pple (Adj)

(3) The reason I'm asking, Celia, is that I don't want to watch, and see you hurt or unhappy, while you throw everything into the effort and then maybe it doesn't work out."

(AH1)

Jag frågar för att jag inte vill se dig bli sårad och olycklig när du satsar allt på det här och sedan kanske inte lyckas."

The complement in these cases is never translated by a that-clause. The verb expresses immediate perception and the proposition is of a perceptual nature (it expresses what is directly perceived).

When see is followed by a that-clause, it makes metalinguistic reference to the proposition (Miller \& Johnson-Laird, 1976:398) and is a source hedging certainty, i.e. it has modal meaning. The speaker reports not a state 'but a fact of it'; the interpretative aspect of see extends to grasping the proposition (Miller \& Johnson-Laird, 1976:599). When see takes a 'factive' complement it can be translated as inse 'realise', förstå 'understand', finna 'find' (cf. Kryk's 1979 description of see as an implicative verb entailing the truth of the complement clause). See itself indicates something about the reliability of the proposition.

TradTerm, 10, 2004, p. 249-277 
(4) I saw that maybe Caroline had mistaken what we were talking about, and spoken as a lawyer when she should have spoken as a daughter.

(JSM1)

Jag insåg att Caroline kanske hade tagit miste på vad vi pratade om, och talat som en advokat i stället för som en dotter.

(5) I see that I don't want to admit that, now, because it comes to me as a criticism, but the truth is that it did give us some sort of security.

(NG1)

Jag märker att jag inte riktigt har lust att erkänna det, nu, därför att det kan låta som kritik, men faktum är att det gav oss trygghet.

Also when se is used in the translation, the complement is factive indicating that it functions as a conclusion and does not report what the subject immediately perceives:

(6) He saw that someone had broken one of the panes in a bow window on the left-hand or West wing of the house.

(RR1)

Han såg att någon slagit sönder en av rutorna i det rundade burspråksfönstret på den vänstra, eller västra, flygeln.

See may be parenthetical:

(7) That, I see now, was our only hope.

(JSM1)

Det, inser jag nu, hade varit vårt enda hopp.

The close relationship between perceiving with one's eyes and understanding has been explained as metaphorical. Sweetser (1984: 51), for example, sees the connection between vision and knowledge as a metaphor conceptualising seeing in terms of knowing. However from another perspective we can think of the relation as a shift from one area of evidentiality to another dependent on the linguistic environment (cf. Traugott $\&$ Dasher 2002: 79).

TradTerm, 10, 2004, p. 249-277 


\section{Translations by a perception verb}

See is one of the most complex verbs in English. The complexity arises both from the problems of defining perception and the multiple meanings associated with see.

G. Lakoff (1987:128) has suggested the following idealised cognitive model (ICM) defining what we take to be the representative cases of 'seeing':

1. You see things as they are.

2. You are aware of what you see.

3. You see what's in front of your eyes.

This model has certain consequences such as the fact that if you see an event, it really happened; moreover, you notice it and know it.

The following translations fall within the domain of perception according to this definition: (kan) se 'can see', få syn på 'catch sight of', få se 'get to see', titta på 'look at'. Seeing may only be implied. If you read something it must for instance be in front of your eyes. It is clear that you can use see even when 'something is not in front of your eyes'. For example, when see refers to understanding it is used as a metaphor for concrete seeing.

\subsection{See translated by the cognate se}

With regard to aspect or aktionsart see is stative, i.e. seeing exists for an undefined period of time (I see well). However see can also occur with can with the meaning of observational success or accomplishment (I can see well). However the modal auxiliary functions more like a progressive expressing duration than a stative verb according to Miller \& Johnson-Laird:

It is as though its stative quality is borrowed in order to express duration. It is inappropriate to say 'He was seeing the mountain' but the sense of this statement is expressed by 'He could see the mountain.'

(Miller \& Johnson-Laird, 1976: 606)

TradTerm, 10, 2004, p. 249-277 
This is illustrated in:

(8) But she could see he was absorbed by something.

(FF 1)

Hon kunde se att han var försjunken i något.

In (9), can see means ability:

(9) "I don’t know how you can see to drive," she said.

(AT1)

"Jag förstår inte hur du kan se att köra”, sade hon.

In (10), can has been omitted in the translation suggesting that it conveys an implication of actuality or truth. According to Panther \& Thornburg (1999:339), ability stands metonymically for the actual process (the cognitive principle 'actuality over potentiality') with verbs of perception and mental process verbs. The potentiality for actuality metonymy is exploited in English with perception verbs. Thus, in the English example, the ability to see stands for the actual perceiving. In Swedish, on the other hand, kan ('can') is not used with perception verbs to indicate that something is actually the case: ${ }^{5}$

(10) “Can you see all right?" Sarah asked.

(AT1)

"Ser du ordentligt?” frågade Sarah.

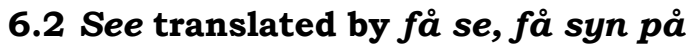

When see is translated as få syn på 'catch sight of' or få se 'get to see' it has ingressive aktionsart (21 examples fick [lit. 'got'], 13 examples får [lit.'get']). Although there exist compound verbs such as 'catch sight of', a simple verb is often used in English in this meaning. The version with få se, fick se is frequent in when (and then) clauses in Swedish and with reference to the future.

5 Cf. also Hungarian where the potentiality for actuality is not exploited for the expression of sense perceptions although it is available to speakers of the language (Panther \& Thornburg, 1999: 340).

TradTerm, 10, 2004, p. 249-277 
(11) But the house, which was a large, unoccupied, neglected, white frame colonial, shocked Andrew when he saw it.

(AH1)

Men huset, som var stort, obebott, misskött, vitmålat och byggt i kolonialstil, chockade Andrew när han fick se det. (lit. 'when he got to see it')

(12) Then he saw me in the doorway.

(BO1)

Så fick han syn på mig i dörröppningen. (lit. 'then he caught/ got sight of me')

(13) And secondly, if she did see what she thought she was going to see, she wouldn't trust herself to keep a straight face. (RD1)

Och för det andra, om hon fick se vad hon trodde att hon skulle få se, var hon inte säker på att hon skulle kunna hålla masken. (lit. 'got to see')

(14) In fact, I had been expecting to shed all concern for time, to see it expand into the space of those southern plains.

(BR1)

Jag hade faktiskt tänkt mig att släppa alla tankar på tid för att få se den flyta ut över vidderna på dessa sydliga slätter. (lit. 'to get to see')

\subsection{Causative see translated as se till att}

Metonymy plays an important role in the area of perception. New metonymies depend on the syntactic environment. A causal metonymy may be seen when seeing something done 'stands for' making sure that it is done. (Radden \& Kövecses, 1999: 39).

(15) I was ready months ago, but when you wrote and said you were comin', I stuck around to see you settled with the baby. (GN1)

Jag var inställd på det för flera månader sedan, men när du skrev och sa att du skulle komma stannade jag kvar för att se till att du kom i ordning med barnet. (lit. 'to see that you came in order')

TradTerm, 10, 2004, p. 249-277 


\subsection{Social contact meanings}

When see is translated by prata med 'talk to', tala med 'speak to', komma på besök 'come to visit', ses 'see each other', it signals that social contact takes place. According to Miller \& Johnson-Laird (1976: 584), implication will account for such extended senses. General world knowledge, perhaps organised as 'scenarios for typical episodes' will explain that the meaning of see can be extended to meet, talk to etc. Cf. Miller \& JohnsonLaird (1976: 585):

...if you meet a person, in the ordinary course of events you see him; if you consult someone, in the ordinary course of events you see him; if you attend a performance of a play, you see the play; if you make sure the drains are unblocked, you see that they are unblocked. See continues to identify seeing but its meaning has been taken to include other aspects of this activity.

The expected translation is ta emot 'receive' rather than se:

(16) The doctor will see you now, Vic thought, amused, and drove the Jag in.

(SK1)

Doktorn tar emot nu, tänkte Vic roat och körde in Jaguaren i ladan.

If you talk to someone you see them. As a result see can extend its meaning to 'talking to someone':

(17) I'd like to see Mr Zablonsky.

(FF 1)

"Jag skulle vilja prata med mr Zablonsky, tack.

A special case of implication is illustrated in (18). See is translated as titta på ('look at'). If you look at someone you mostly see them. Titta is more active and is intentional. The subject came here in order to do something:

(18) "He never came here to see his horses.

(DF1)

"Han kom aldrig hit för att titta på sina hästar.

TradTerm, 10, 2004, p. 249-277 


\section{See with non-perception meanings}

What is interesting about see is that it has cognitive polysemic uses, such as see meaning 'understand' or see = 'evaluate as'. I will refer to such cases as amalgamation between perceptual and cognitive meanings. Other examples of amalgams between perception and cognition are I feel that = 'I think that' or I hear that = 'I have been told that'.

See can sometimes be translated by höra 'hear' or by känna på sig att 'feel' but never by verbs expressing taste or smell which do not allow more abstract interpretations (Miller \& JohnsonLaird, 1976: 600; Viberg, 1984: 157f). In (19), see is an amalgamation between seeing and hearing:

(19) Why don't you wait and see what they have to say first? (SG1)

Varför väntar du inte tills du får höra vad de kommer fram till? (lit. 'get to hear')

\subsection{See as a cognitive verb}

It seems to be fairly common that a verb of perception receives the meaning of know, understand or think through semantic extension. Thus there are languages where see and know are expressed by a single verb (Viberg, 1984:157). See is not a perception verb but a cognitive verb in such cases. Actual seeing is not involved in any of the examples below:

(20) Do you see what I mean?

(JB1)

Förstår ni vad jag menar?

Just like that-complements, the wh-complement is interpreted metalinguistically with reference to a question rather than with 'ordinary reference' to an object (cf. Miller \& Johnson-Laird, 1976: 597). Metalinguistically a wh-complement can refer to the meanings of certain questions ( $w h$-questions such as 'he asked whether it was raining') and to complements referring to answers

TradTerm, 10, 2004, p. 249-277 
to such questions ('he told them whether it was raining'). In (20) the speaker asks about something equivalent to a wh-question where $\mathrm{X}$ has a certain value ('I mean $\mathrm{X}$ ').

In (21)-(23), on the other hand, it is clear that the meaning of the question is referred to:

(21) The later volumes seem to be attracting the most attention but, at the moment, I can't see why.

(MW1)

Det är de senaste böckerna som tycks dra till sig störst uppmärksamhet, men just nu förstår jag inte varför.

(22) "I don't see why.

(JSM 1 )

"Jag förstår inte varför.

(23) I followed her and saw what she meant about mess.

(DF1)

Jag följde efter henne och förstod vad hon menade med oreda.

In (24), the subject looked at an object (that which they had come to see). See cannot be translated by förstå:

(24) They stood a few feet into the room, on thick carpet, and saw what they had come to see.

(RR1)

De stod någon meter inne i rummet, på en tjock matta, och såg det som de kommit dit för att se.

\subsection{Discourse particle uses of see}

The perception verb see but not hear can be used as a discourse marker (Schiffrin, 1987: 327): you see, I see and see. The semantic component of cognition is important to explain how see develops into a discourse marker and can be shown in the translations (cf. Usoniene, 2001). In (25) see is used in explanations as a connective ('the reason is'):

TRADTERM, 10, 2004, p. 249-277 
(25) Sorry, it would be embarrassing to have Arthur's wife; I'm having this affair with her husband, you see?

(FW1) "Jag är ledsen, men det vore genant att bjuda Arthurs fru. Jag har nämligen en historia med hennes man."

(26) See, we don't want to waste our time for nothing." (DF1) Ni förstår, vi vill inte ödsla vår tid på ingenting."

(27) "You see," he said, "eating cane is like living life." (GN1)

"Att äta sockerrör är som att leva, förstår du", sa han.

I see is used to indicate the reception of new knowledge.

As discourse particles, I see, you see and see do not belong to the proposition but are placed outside the utterance in the pre-front field or end-field (or parenthetically inside the proposition). Since they do not belong to the proposition they are often omitted by the translator. On the textual level they have a connective function and interpersonally they work as markers of solidarity and politeness. The main function of $I$ see is to provide a feedback signal when the information has been received:

(28) "I see," said Cooper kindly.

(MW1)

“Jag förstår", sade Cooper vänligt.

\subsection{See and evaluation}

In the syntactic pattern 'see as', the verb is evaluative and is translated by betrakta som ('regard as'):

(29) He knew that through mere chance, a fluke engineered by what he now saw as this remarkable and delightful young woman seated opposite, he had participated in a piece of medical history.

(AH1)

TradTerm, 10, 2004, p. 249-277 
Han visste att han av en ren tillfällighet, tack vare denna unga kvinna som han nu betraktade som fantastisk och förtjusande, hade fått uppleva ett stycke medicinsk historia.

\section{To see omitted in the translation.}

A translation corpus can give indications about semantic bleaching as well as about principled changes towards more grammatical or more pragmatic meanings (cf. Mair, 1994).

Look/check/watch to see signal that there is an intention to see something (the subject checks or looks at something in order to see). Check to see was especially frequent in my material. In the translations, see either disappears or a particle verb is used. In (30), to see has disappeared in the translation suggesting that its meaning has been weakened:

(30) He tugged the last of the forty smaller stones from the gold settings and checked to see he had missed none.

(FF1)

Han lossade den sista av de fyrtio mindre stenarna ur infattningen och kontrollerade att han inte hade missat någon.

(31) She was checking to see that he wasn't telling a lie

(RDO1)

Hon ville kolla att han inte ljög.

The translation by means of a particle verb (se efter, se till) suggests that the function of check to is to express aspectual distinctions which are not expressed by see and that see has an intentional component (something is done for a reason). In (32), check has the progressive form to express duration:

(32) "She was checking to see how you 're doing. (AT1)

"Hon ville se efter hur du klarade dig.

The function of check to makes it possible to express manner:

TradTerm, 10, 2004, p. 249-277

10 TradTerm 11.pmd 
(33) He shut the heavy curtains and checked carefully to see that there were no gaps.

(HM1T)

Han drog för de tunga gardinerna och såg noga till att där inte fanns några glipor.

(34) We look at earwax, or snot, or dirt from our toes, checking first to see that there's no one around: we know without asking that such things would not be approved of.

(MA1)

Vi tittar på öronvax, snor, eller smuts från våra tår, efter att först ha sett efter att det inte finns någon i närheten vi vet utan att fråga att sådana saker inte skulle gillas.

Watch to is another way in which one can express an intention to do something. As indicated by the translation, I believe watch implies duration and carefulness:

(35) He watched to see which soapies called out his name and waved, which ones had customers and which had none.... (JC1)

Han noterade noga vilka av torghandlarna som ropade efter honom och vinkade, vilka som hade kunder och vilka inte ... (lit. 'he noted carefully which soapies...)

Look to see is another way of expressing 'seeing with a certain intention' (cf. Mair 1994: 134). According to Mair, to see does not function adverbially as a purpose clause after look. It cannot for instance be replaced by a purpose clause ('we looked in order to see'). In (36) the translator has chosen a single verb (kolla 'check'), and in (37) he has used a particle verb (titta efter om 'look after if'):

(36) We got into the gap and looked to see if there was anyone coming to get us.

(RDO1)

Vi kröp in i öppningen och kollade om det var någon efter oss.

(37) I kept wanting to look in the closet to see if I could find the guy a sandwich board."

TradTerm, 10, 2004, p. 249-277 
(SK1)

Jag hade lust att titta efter i skrubben om det inte fanns ett sandwichplakat åt gubben."

In (38), to see has been omitted because it is redundan with an emotional predicate:

(38) They had liked him, I was glad to see.

(DF1)

De hade alla tyckt om Greville och det gladde mig.

(lit. 'gladdened me')

In the next example the translator has used a synthetic verb with the meaning 'cause to be glad' with the result that to see has disappeared in the translation:

(39) But he was masochistically pleased to see that the Mets were off to another superlatively cruddy start. (SK1)

Men han var masochistiskt förtjust över att Mets verkade vara på väg mot ännu en urusel säsongstart. ('lit. pleased at that')

In (40), to see changes the complement clause from expressing what is immediately perceived to a fact. The translator has used a that-clause corresponding to to see.

(40) They were gratifyingly sorry to see him go.

(FF1)

De tyckte glädjande nog att det var tråkigt att han skulle försvinna.

(lit. They thought gratifyingly enough that it was sad that he would disappear'.)

See does not always indicate that something is immediately perceived. In (41), the implication is that the young couple were surprised at the fact that the old men were sitting there drinking coffee. The translator has expressed the same meaning by a that-clause:

TradTerm, 10, 2004, p. 249-277 
(41) A young couple walked briskly round the corner of the house, surprised to see three old men sitting there drinking coffee. (SC1T)

Ett ungt par kommer raskt gående runt husknuten och dom blir överraskade av att här sitter tre gubbar och dricker kaffe. (lit. 'surprised by that')

\section{Conclusion}

At a general level, the verbs see and se are similar to each other as might be expected from the fact that they are cognates and we are comparing related languages. Both refer to the situation of perceiving with one's eyes but the verbs diverge in their further developments. It follows that translations into Swedish can be used to get a better picture of the meaning extensions that have taken place in English.

The various senses of see depend to a large extent on the grammatical context, in particular its type of complementation. It is typical of nuclear verbs like see that they extend their meanings into domains such as evidentiality, aspect and causation. When see is followed by a that-clause or a wh-clause its status is metalinguistic and it refers to 'seeing' as the source of knowledge for drawing a conclusion rather than to 'seeing itself.' In combinations with emotion verbs (I regret to see), to see signals factive meaning rather than 'seeing.' When followed by a whclause, its function can be compared with that of giving an answer to a question or offering an explanation for a problem. Meanings also extend into discourse by means of processes such as 'pragmaticalisation'. Pragmaticalisation provides an explanation for those cases when e.g. I see, you see are no longer part of the proposition, taking on meanings that can be accounted for on the interpersonal or textual level.

In particular, see can have aspectual meanings not defined by the prototypical see. See can, for instance, express stative or durative aktionsart (together with can) and is used with an ingressive reading (Swedish translation få se, få syn på). See in the syntactic pattern see+NP+Ved is causative. See can be agentive (titta på 'look') but it does not yet occur alone with an intentional component (cf. check to see).

TradTerm, 10, 2004, p. 249-277 
Seeing can also extend its meanings on the basis of conceptual schemas or frames (e.g. doctor seeing patients) in which perceptual seeing is involved. However, when seeing is related to reading, the extension of meaning cannot be explained within the confines of grammar; it results from the knowledge that reading a book entails seeing it. When we look at more languages, we can expect the number of such culture-dependent extensions to increase.

\section{Primary sources}

The abbreviations used in the article are given in parentheses.

Atwood, Margaret. 1988. Cat's eye. Toronto: McClelland and Stewart. (AT1) Barnes, Julian. 1991. Talking it over. London: Jonathan Cape. (JB1)

Brink, André. 1985. The wall of the plague. London: Flamingo/Fontana Paperbacks. (BR1)

Crace, Jim. 1992. Arcadia. London: Jonathan Cape. (JC1)

Doyle, Roddy. 1993. Paddy Clarke ha ha ha. London: Secker \& Warburg. (RDO1)

Forsyth, Frederick. 1984. The fourth protocol. London: Hutchinson. (FF1)

Francis, Dick. 1989. Straight. London: Michael Joseph Ltd. (DF1)

Gordimer, Nadine. 1991. My son's story. London: Penguin Books (NG1) Grafton, Sue. 1990. “D” is for deadbeat. London: Pan Books Ltd. (SG1)

Hailey, Arthur. 1984. Strong medicine. Michael Joseph Ltd. (AH1)

King, Stephen. 1981. Cujo. Penguin Books USA Inc. (SK1)

Naylor, Gloria. 1980. The women of Brewster Place. London: Hodder \& Stoughton. (GN1)

Okri, Ben. 1991. The famished road. London: Jonathan Cape. (BO1)

Rendell, Ruth. 1992. Kissing the gunner's daughter. London: Hutchinson. (RR1)

Smiley, Jane. 1991. A thousand acres. London: Flamingo HarperCollins. (JSM 1)

Tyler, Anne. 1985. The accidental tourist. New York: Alfred A. Knopf. (AT1)

Walters, Minette. 1994. The scold's bride. London: Pan Books/Macmillan General Books. (MW1)

Weldon, Fay. 1987. The heart of the country. London: Hutchinson. (FW1)

TradTerm, 10, 2004, p. 249-277 


\section{References}

ALM-ARVIUS, C. (1991) The English verb see: a study in multiple meaning. Department of English. University of Göteborg.

ALTENBERG, B. \& AIJMER, K. (2000) The English-Swedish Parallel Corpus: a resource for contrastive research and translation studies. In: Mair, C. \& M. Hundt (eds.) Corpus linguistics and linguistic theory. Papers from the 20th International Conference on English Language Research on Computerized Corpora (ICAME 20) Freiburg im Breisgau 1999. Amsterdam \& Philadelphia, Rodopi, p. 15-33.

ALTENBERG, B. \& GRANGER, S. (1996) Recent trends in cross-linguistic studies. In: Altenberg, B. \& S. Granger (eds.) Lexis in contrast. Corpusbased approaches. Amsterdam/Philadelphia, John Benjamins Publishing Company, p. 3-48.

CHAFE, W. (1986) Evidentiality in English conversation and academic writing. In: Chafe \& Nichols (eds.) below, p. 261-72.

CHAFE, W.; NICHOLS, J. (eds.) (1986) Evidentiality: The linguistic coding of epistemology. Norwood, NJ, Ablex.

FRANCIS, W.N. \& KUCERA, H. (1982) Frequency analysis of English usage. Lexicon and grammar. Boston, Houghton Mifflin Company.

HASSELGÅRD, H. and OKSEFJELL, S. (eds.) Out of corpora. Studies in honour of Stig Johansson. Amsterdam \& Atlanta, GA, Rodopi.

JOHANSSON, S. and OKSEFJELL, S. (eds.) (1998) Corpora and crosslinguistic research: theory, method and case studies. Amsterdam \& Atlanta, GA, Rodopi.

KRYK, B. (1979) How factive are see, hear, feel and their Polish equivalents? In: Fisiak, J. (ed.) Papers and studies in contrastive linguistics. Poznan and Arlington, VA, Center for Applied Linguistics, vol. 9, p. 147-64.

LAKOFF, G. (1987) Women, fire and dangerous things. What categories reveal about the mind? Chicago and London, The University of Chicago Press.

MAIR, C. (1994) Is see becoming a conjunction? The study of grammaticalisation as a meeting ground for corpus linguistics and grammatical theory. In: Fries, U., Tottie, G. \& Schneider, P. (eds.) Creating and using English language corpora. Papers from the Fourteenth International Conference on English Language Research on Computerized Corpora, Zürich 1993. Amsterdam \& Atlanta, GA, p. 127-37.

MILLER, G. A. \& JOHNSON-LAIRD, P. N. (1976) Language and perception. Cambridge, Cambridge University Press.

TRADTERM, 10, 2004, p. 249-277 
NOËL, D. (2002) Believe-type matrix verbs and their complements. Corpus-based investigations of their functions in discourse. A collection of articles. Vakgroep Engels, Universiteit Gent.

PANTHER, K-U. \& RADDEN, G. (eds.) (1999) Metonymy in language and thought. Amsterdam/Philadelphia, John Benjamins Publishing Company.

PANTHER, K-U. \& THORNBURG, L. (1999) The potentiality for actuality metonymy in English and Hungarian. In: Panther \& Radden (eds) above, p. 333-57.

RADDEN, G. \& KÖVECSES, Z. (1999) Towards a theory of metonymy. In: Panther \& Radden (eds.) above, p. 17-59.

SCHIFFRIN, D. (1987) Discourse markers. Cambridge, Cambridge University Press.

SWEETSER, E.E. (1984) Semantic structure and semantic change: a cognitive. linguistic study of modality, perception, speech acts, and logical relations. UMI (University Microfilms International) Dissertation Information Service.

TRAUGOTT, E. C. \& DASHER, R. B. (2002) Regularity in semantic change. Cambridge, Cambridge University Press.

USONIENE, A. (2002) On syntax-semantics interface: verbs of perception in English and Lithuanian. Department of English Philology, University of Vilnius.

VIBERG, A. (1984) The verbs of perception. A typological study. In: Butterworth, B., Comrie, B. \& Dahl, Ö. (eds.) Explorations for language universals. Berlin/New York/Amsterdam, Mouton Publishers, p. 12362.

. (1996) Cross-linguistic lexicology. The case of English go and Swedish gå. In: Aijmer, K. \& Altenberg, B. (eds.) Languages in contrast. Papers from a symposium on text-based cross-linguistic studies. Lund 4-5 March 1994. Lund, Lund University Press, p. 151-82.

TradTerm, 10, 2004, p. 249-277 


\section{Appendix 1}

Table 1a: Swedish translations of English see: see(s)

\begin{tabular}{|l|c|}
\hline se ('see') & 145 \\
\hline få syn på ('catch sight of') & 10 \\
\hline inse ('realise') & 6 \\
\hline träffa ('meet') & 5 \\
\hline se som ('see as') & 5 \\
\hline betrakta som ('regard as') & 4 \\
\hline få se ('get to see') & 3 \\
\hline anse ('think') & 2 \\
\hline läsa ('read') & 2 \\
\hline ta emot ('receive') & 1 \\
\hline finna ('find') & 1 \\
\hline förstå ('understand') & 1 \\
\hline uppfatta som ('understand as') & 1 \\
\hline utläsa ('read', 'interpret') & 1 \\
\hline stirra på ('stare at') & 1 \\
\hline uppfatta ('understand') & 1 \\
\hline tycka sig ana ('imagine') & 1 \\
\hline märka ('notice') & 1 \\
\hline prata med ('talk to') & 1 \\
\hline upptäcka ('discover') & 1 \\
\hline hitta ('find') & 1 \\
\hline paraphrase & 2 \\
\hline$\varnothing$ & 1 \\
\hline other & 63 \\
\hline Total & \\
\hline
\end{tabular}

TradTerm, 10, 2004, p. 249-277 
Table 1b: Swedish translations of English see: saw

\begin{tabular}{|l|r|}
\hline se ('see') & 254 \\
\hline förstå ('understand') & 28 \\
\hline få se ('get to see') & 18 \\
\hline träffa ('meet') & 12 \\
\hline titta på ('look at') & 5 \\
\hline inse ('realise') & 5 \\
\hline ses ('see each other') & 4 \\
\hline fatta ('understand') & 3 \\
\hline märka ('notice') & 3 \\
\hline hälsa på ('visit') & 3 \\
\hline prata med ('talk to') & 3 \\
\hline ta hand om ('take care of') & 3 \\
\hline få syn på ('catch sight of') & 3 \\
\hline ta emot ('receive') & 2 \\
\hline prova ('try') & 1 \\
\hline upptäcka ('discover') & 1 \\
\hline märkas ('be noticeable') & 1 \\
\hline visa ('show') & 1 \\
\hline undersöka ('investigate') & 1 \\
\hline fråga om ('ask if') & 1 \\
\hline begripa ('understand') & 1 \\
\hline komma på besök ('come to visit') & 1 \\
\hline tala med ('talk to') & 1 \\
\hline titta till ('look up') & 1 \\
\hline få höra ('get to hear') & 1 \\
\hline få någon att göra något ('get sb to do sth') & 1 \\
\hline höra efter ('hear if') & 1 \\
\hline tycka att ('think') & 1 \\
\hline känna på sig att ('feel') & 1 \\
\hline möta ('meet') & 1 \\
\hline tänka sig att ('imagine') & 1 \\
\hline paraphrase & 1 \\
\hline omission & 1 \\
\hline other (unsatisfactory translations) & 1 \\
\hline Total & 1 \\
\hline
\end{tabular}

TRADTERM, 10, 2004, p. 249-277 
Table 1c: Swedish translations of English see: seeing

\begin{tabular}{|l|c|}
\hline se ('see') & 18 \\
\hline betrakta ('regard') & 3 \\
\hline träffa ('meet') & 4 \\
\hline inse ('realise') & 1 \\
\hline other & 1 \\
\hline Total & 27 \\
\hline
\end{tabular}

Table 1d: Swedish translations of English see: seen

\begin{tabular}{|l|r|}
\hline se ('see') & 118 \\
\hline träffa ('meet') & 5 \\
\hline synas (till) ('be visible') & 5 \\
\hline skymta ('glimpse', 'there is a glimpse of') & 2 \\
\hline visa sig ('appear') & 2 \\
\hline möta ('meet') & 2 \\
\hline uppfatta som ('understand as') & 1 \\
\hline höra av ('hear from') & 1 \\
\hline vara hos ('be with') & 1 \\
\hline fatta ('grasp') & 1 \\
\hline begripa ('understand') & 1 \\
\hline ta emot ('receive') & 1 \\
\hline titta på ('look at') & 1 \\
\hline få syn på ('catch sight of') & 1 \\
\hline other & 6 \\
\hline omission & 3 \\
\hline Total & 153 \\
\hline
\end{tabular}

Table 1e: Translations of see organised according to meaning

\begin{tabular}{|l|c|}
\hline A. Perception & \\
\hline se ('see') & 535 \\
\hline få se ('get to see') & 21 \\
\hline få syn på ('catch sight of') & 14 \\
\hline visa ('show)' & 1 \\
\hline skymta ('glimpse') & 2 \\
\hline synas ('be seen') & 5 \\
\hline B. Extended uses of seeing & \\
\hline Reading as seeing & \\
\hline läsa ('read') & 2 \\
\hline utläsa ('read out', 'interpret') & 1 \\
\hline
\end{tabular}

TradTerm, 10, 2004, p. 249-277 


\section{5}

\begin{tabular}{|l|c|}
\hline Social contact & \\
\hline hälsa på ('visit') & 3 \\
\hline träffa ('meet') & 26 \\
\hline ta emot ('receive') & 4 \\
\hline prata med ('talk to') & 4 \\
\hline ses ('see each other') & 4 \\
\hline tala med ('speak to') & 1 \\
\hline komma på besök ('come to visit') & 1 \\
\hline titta in till ('visit') & 1 \\
\hline möta ('meet') & 3 \\
\hline ta hand om ('take care of') & 3 \\
\hline höra av ('hear from') & 1 \\
\hline vara hos ('be with') & 1 \\
\hline Seeing as behaviour & \\
\hline stirra på ('stare at') & 1 \\
\hline titta på ('look at') & 6 \\
\hline Causative & \\
\hline se till att ('see that sth is done') & $?$ \\
\hline få någon att göra något ('get sb do sth') & 1 \\
\hline Seeing if & \\
\hline undersöka om ('investigate if') & 1 \\
\hline fråga om ('ask if') & 1 \\
\hline kontrollera ('check') & 1 \\
\hline kolla ('check') & 4 \\
\hline prova om ('try if') & 1 \\
\hline titta efter om ('check if') & 2 \\
\hline höra efter ('hear if') & 1 \\
\hline C. Cognition & 2 \\
\hline anse ('think') & 2 \\
\hline förstå ('understand') & 1 \\
\hline uppfatta ('grasp') & 1 \\
\hline inse ('realise') & 1 \\
\hline fatta ('grasp') & 1 \\
\hline begripa ('understand') & 1 \\
\hline veta ('know') & 1 \\
\hline tycka sig ana ('imagine') & \\
\hline märka ('notice') & \\
\hline /få/ höra ('hear') & 1 \\
\hline tycka att ('think') & \\
\hline känna på sig att ('feel') & \\
\hline tänka sig att ('imagine') & \\
\hline
\end{tabular}

TradTerm, 10, 2004, p. 249-277 


\begin{tabular}{|l|c|}
\hline finna ('find') & 1 \\
\hline upptäcka ('discover') & 2 \\
\hline hitta ('find') & 1 \\
\hline märkas ('be noticeable') & 1 \\
\hline D. Evaluation & \\
\hline se som ('see as') & 5 \\
\hline betrakta som ('regard as') & 7 \\
\hline se på (som) ('see as') & 5 \\
\hline uppfatta som ('understand as') & 2 \\
\hline
\end{tabular}

\section{Appendix 2}

Table 2a: Idioms with see

Table 2a: Idioms with see
\begin{tabular}{|l|l|l|}
\hline see sb out & 'följa någon ut' & 'follow sb out' \\
\hline see to sth & $\begin{array}{l}\text { 'ordna', 'se till', 'ta itu } \\
\text { med', 'ta reda på' }\end{array}$ & 'find out about' \\
\hline see sb to a /vehicle/ & 'eskortera till' & \\
\hline see sb off the premises & 'skicka hem' & 'send home' \\
\hline go to see & 'söka upp' & 'look for' \\
\hline take to see & 'ta med sig till' & 'take with one to' \\
\hline pop over to see & 'titta in till' & 'look in to see' \\
\hline come to see & 'komma hit' & 'come here' \\
\hline see again & 'återse' & \\
\hline see films & 'gå på bio' & 'go to the cinema' \\
\hline see an opportunity & 'få ett tillfälle' & 'get an opportunity' \\
\hline see fit & 'tro vara bäst' & 'think to be best' \\
\hline see sb off & 'vinka av någon' & 'wave goodbye to sb' \\
\hline see through & 'genomskåda' & \\
\hline see a point & 'märka' & 'notice' \\
\hline see eye to eye & 'förstå varandra' & 'understand each other' \\
\hline
\end{tabular}

Tables 2b: Discourse particle use

\begin{tabular}{|c|c|c|c|c|}
\hline you see & 'nämligen' (name & & I see & 'jaså' (c \\
\hline & 'ska ni veta' (you & low) & & på det $\mathrm{s}$ \\
\hline & 'du förstår' (you & and) & & \\
\hline & not translated $3 \mathrm{e}$ & & & \\
\hline & see & fakti & & \\
\hline & & 'vac & g sa (w & id I say) \\
\hline & & not $t$ & examp & \\
\hline
\end{tabular}

TradTerm, 10, 2004, p. 249-277 
Appendix 3: Some Swedish idioms with see

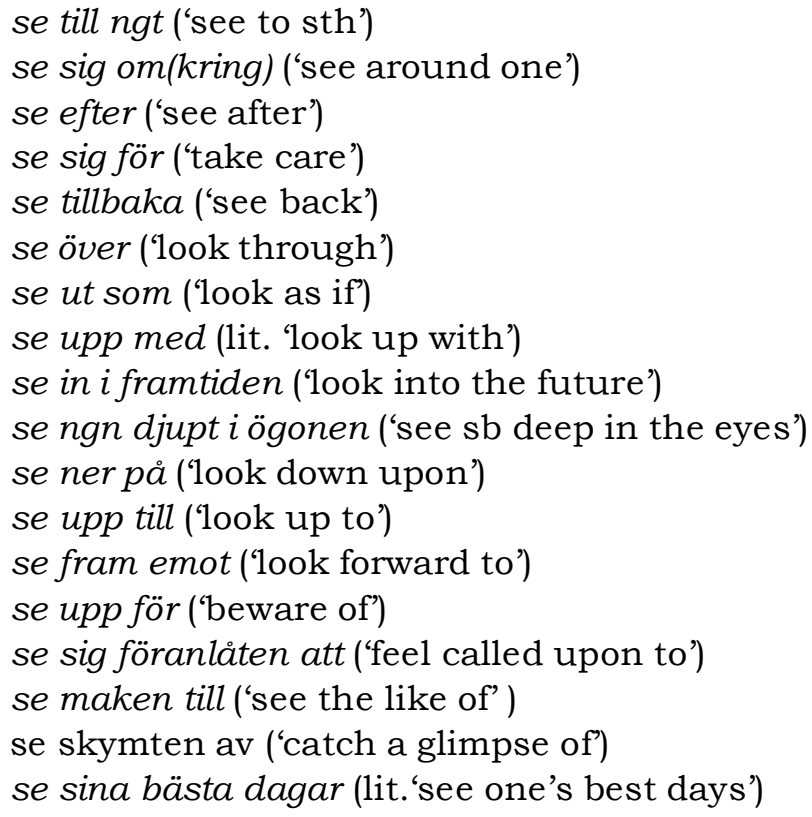

TradTerm, 10, 2004, p. 249-277 